Nothing is known of this worm or its habits except what is revealed by this one glimpse of its life at mating time. It has never been taken, so far as I have been able to discover, except during these evolutions, and even these would be wholly unknown except for this momentary phosphorescence which accompanies the maturation of the sexual cells. Whether it is a burrowing type which comes to the surface only at this time, or a pelagic type swept in by the tides, we are not sure. Occasionally Foraminifera are found caught among the setæ; this suggests that it may have its home on the bottom.

Naturally the facts above stated make the worm a favorable organism for the study of embryology. Abundance of material can be had, and the moment of fertilization can be approximated with much closeness; two items quite essential in such studies. The following schedule of some of the early developmental stages may be interesting to some of you:

1. Eggs fertilized about 8 o'clock.

2. Ciliated and rotating blastulas at midnight (4 hours).

3. Gastrulation occurred numerously between the fourth and sixth hours.

4. Eye spots developed in ectoderm in 6 to 7 hours.

5. The ectodermic invaginations to form mouth and anus about 7 hours.

6. Shows signs of metameric segmentation in posterior region of trochosphere about the eighteenth hour.

7. Bristles of the dorsal bundles begin to be apparent 29-30 hours.

Read at first meeting of the Illinois Academy of Science, at Decatur, I11., February 22, 1908.

\title{
A LINEAR EXPANSION APPARATUS.'
}

By Clarence M. Hall,

Central High School, Springfield, Mass.

A simple, inexpensive apparatus for measuring the linear coefficient of expansion of brass, which has given good results in students' hands is here described:

A quarter inch brass tube about three feet long is mounted on a wood base as shown in the figure. One end of the tube passes

$\overline{1}_{T}$ The cut is a representation of the linear expansion apparatus described in this article and was kindly lóned by the makers of the apparatus, the Cambridge Botanical Supply Co. 
easily through a screw eye, projecting about one inch; the other end fits snugly without backlash, down over a taper pin which passes through a small hole drilled in the tube. This last end of the tube should project over the end of the wood base, to prevent the steam used from wetting the base.

About one-quarter inch from the screw eye, toward the taper pin, is made a prick punch mark in the side of the titbe. Into this mark or dent fits one of the conical ends of a short steel rod, while the other end of this rod, also conical, fits into a prick punch mark in a brass piece screwed to the wood base. These conical points are hardened and ground.

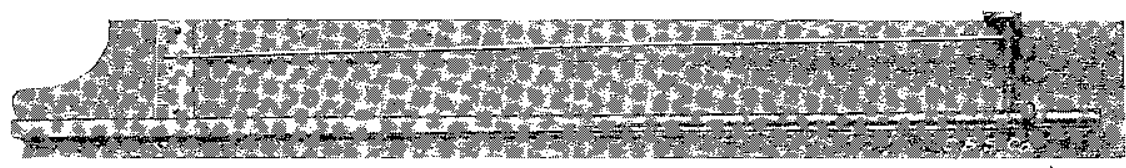

Through this steel rod is riveted a long steel index or pointer, which moves over a paper millimeter scale on the base.

In use, the tube is lifted up off the taper pin and the index is then removed, by sliding the tube out of the screw eye.

The distance from the tapar pinhole to the prick punch mark is the cold length of the brass. The short arm of the lever is measured by a vernier beam caliper, measuring to one-tenth millimeter, by calipering the outside dimension of the extreme points. The long arm is the distance from the end of the index wire back to the point of the rod nearest it.

The steam temperature is obtained from the barometer reading.

The apparatus is assembled and steam led through it from a boiler, by a tube slipped over the end of the brass tube passing through the screw eye, and in a few seconds the expansion is complete and the index may be read.

The following data were obtained by a student with the above apparatus:

Barometer ...................... $75.9 \mathrm{~cm}$.

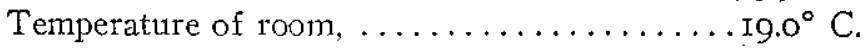

Length of tube, $\ldots \ldots \ldots \ldots \ldots \ldots \ldots \ldots \ldots .83 .8 \mathrm{~cm}$.

Length of short arm of lever,.............

Length of long arm of lever, ............

Reading of index at temperature of room,.... $1.22 \mathrm{~cm}$.

Reading of index after expansion was complete, $2.34 \mathrm{~cm}$.

The above data give by calculation, 0.0000188 for the coefficient. 